\title{
Pesan Moral dan Nilai Pendidikan dari Simbolik Lemper Raksasa dalam Upacara Adat Rebo Pungkasan
}

\author{
Ika Damayanti \\ Universitas Islam Negeri (UIN) Sunan Kalijaga Yogyakarta \\ ikadamayantiwae12345@gmail.com \\ Muhammad Shaleh Assingkily \\ Universitas Islam Negeri (UIN) Sunan Kalijaga Yogyakarta email: \\ assingkily27@gmail.com \\ Izzatin Kamala \\ Universitas Islam Negeri (UIN) Sunan Kalijaga Yogyakarta email: \\ izaatinkamala@gmail.com
}

\begin{abstract}
The traditional ceremony of rebo pungkasan is a cultural ritual that has been traditionally carried out by the Javanese people, including the Wonokromo Village community as an expression of gratitude to Allah. This ritual uses lemper raksasa as a special icon that contains moral messages for elementary children. The purpose of this paper is to discuss the moral message contained in lemper raksasa in the traditional ceremony rebo pungkasan for elementary age children. Therefore, as a formulation of the discussion, what moral messages from lemper raksasa for elementary-age children, how the moral message was given and why the tradition is worth preserving. This paper used a qualitative approach with the background of rebo pungkasan carried out by the people of Wonokromo Village, Pleret District, Bantul Regency, DIY. The results of this study indicate that (1) lemper raksasa is symbolically valued moral message to children of primary age, in the form of 'daun pisang' (banana leaves) as a symbol of the 'problem' learning of children, 'ketan' (sticky rice) as a symbol of 'initial enjoyment' of children's learning and minced meat as a symbol of learning to become a 'provision of life' of children; (2) the symbolic moral message is given to children by inviting children to rebo pungkasan and to internalize it verbally to each child; (3) to preserve the culture, it is functioned as a means of entertainment, tourism assets, a media of 'silaturahmi' and a means of social integration.
\end{abstract}

Keywords: Elementary age children, Lemper raksasa, Moral messages, Rebo pungkasan.

\begin{abstract}
Abstrak: Upacara adat Rebo Pungkasan merupakan ritual yang secara turun-temurun dilaksanakan masyarakat suku Jawa termasuk masyarakat Desa Wonokromo sebagai ungkapan rasa syukur kepada Allah swt. Ritual ini menggunakan lemper raksasa sebagai khas simbolik yang mengandung pesan moral bagi anak usia dasar. Tulisan ini mengkaji lebih lanjut terkait pesan moral yang terkandung dari lemper raksasa dalam upacara adat rebo pungkasan bagi anak usia dasar. Untuk itu, sebagai formulasi pembahasan dikaji apa saja pesan moral dari lemper raksasa dalam upacara adat rebo pungkasan bagi anak usia dasar, bagaimana pesan moral itu diberikan, serta bagaimana tradisi tersebut dilestarikan. Penelitian ini menggunakan pendekatan kualitatif dengan latar upacara adat rebo pungkasan yang dilaksanakan masyarakat
\end{abstract}

Belajea: Jurnal Pendidikan Islam Vol. 5, No 2, 2020; 339-358

p-ISSN 2548-3390; e-ISSN 2548-3404, DOI:10.29240/belajea.v5i2.1231

http://journal.iaincurup.ac.id/indek.php/belajea 
340 | Belajea: Jurnal Pendidikan Islam, Vol. 5, No. 2, 2020

Desa Wonokromo Kecamatan Pleret Kabupaten Bantul-DIY. Adapun hasil penelitian ini menunjukkan bahwa (1) lemper raksasa bernilai pesan moral secara simbolik kepada anak usia dasar, berupa daun pisang sebagai simbol 'masalah' belajar anak, ketan sebagai simbol 'kenikmatan awal' belajar anak dan daging cincang sebagai simbol belajar menjadi 'bekal kehidupan' anak; (2) pesan moral simbolik itu diberikan kepada anak dengan mengajak anak menyaksikan langsung rebo pungkasan dan menginternalisasikannya secara lisan kepada anak masing-masing; (3) untuk melestarikan budaya tersebut, maka difungsikan sebagai sarana hiburan, aset pariwisata, media silaturahmi dan sarana integrasi sosial.

Kata Kunci: Anak usia dasar, Lemper Raksasa, Pesan moral, Rebo Pungkasan.

\section{Pendahuluan}

Budaya merupakan 'cita rasa' khas suatu kelompok, komunitas, atau masyarakat yang mendiami daerah tertentu. Nilai unik suatu budaya ${ }^{1}$ tentu tidak hadir begitu saja, melainkan memiliki rentetan historis yang penuh makna dalam menjunjung tinggi nilai luhur ${ }^{2}$ yang diturunkan orang-orang sebelumnya. Sehingga, dapat dikatakan bahwa budaya lahir atas upaya menjaga nilai luhur yang diyakini membawa kemaslahatan bagi masyarakat.

Nilai keluhuran suatu budaya mencerminkan derajat dan tingkat peradaban manusia, ${ }^{3}$ hal ini ditunjukkan melalui kepatuhan atas norma-norma yang disepakati bersama, serta penghayatan dan pengamalan terhadap tatanan nilai yang menyertainya. Bahkan bilamana masyarakat pendatang memasuki suatu kawasan atau daerah dilazimkan pada penghormatan akan adat-istiadat budaya setempat. Hal ini menjadi semacam 'konsensus' yang dipahami masyarakat Indonesia.

Kemajemukan masyarakat di Indonesia sendiri, tidaklah 'diwarnai' unsur perbedaan suku dan etnis serta ras bahkan agama yang ada, sebab kesemuannya dipandang sebagai kekayaan bangsa Indonesia. Bahkan dalam konteks ini, budaya dianggap menjadi 'titik simpul' keragaman dapat bersatu, serta cara tepat

${ }^{1}$ I Gusti Bagus Rai Utama, "Keunikan Budaya dan Keindahan Alam Sebagai Citra Destinasi Bali Menurut Wisatawan Australia Lanjut Usia" Jurnal Kajian Bali (Journal of Bali Studies) 6 (1), 2016. https://ojs.unud.ac.id/index.php/kajianbali/article/view/19904. Lihat Susana Widyastuti, "Peribahasa: Cerminan Kepribadian Budaya Lokal dan Penerapannya di Masa Kini." Proceeding of National Seminar of Yogyakarta. http://staffnew.uny.ac.id/upload/132316016/penelitian/Peribahasa+Cerminan+Kepribadian+ Budaya+Lokal.pdf.

${ }^{2}$ Dadan Iskandar, "Identitas Budaya dalam Komunikasi Antar-Budaya: Kasus Etnik Madura dan Etnik Dayak" Jurnal Masyarakat dan Budaya 6 (2), 2004: 119-140. http://imb.lipi.go.id/index.php/imb/article/view/208/188.

${ }^{3}$ Koentjaraningrat, Metode-metode Antropologi dalam penyelidikan Masyarakat dan Kebudayaan Indonesia, (Jakarta: UI Press, 1990), h. 217. 
dalam meminimalisir konflik yang ada. Sebut saja masyarakat suku Jawa, mulai dari bahasa, ${ }^{4}$ seni, hingga ritual kebudayaannya ${ }^{5}$ memiliki nilai filosofis yang dijunjung tinggi.

Ritual kebudayaan masyarakat Jawa yang terkenal salah satunya yakni upacara adat rebo pungkasan. ${ }^{6}$ Ritual berupa ungkapan rasa syukur ini secara turun-temurun dilaksanakan masyarakat suku Jawa di berbagai daerah dengan 'teknis' pelaksanaan yang berbeda sesuai kearifan lokal daerahnya. Senada dengan ini, penelitian terkait upacara rebo pungkasan pun telah ditinjau dari berbagai aspek, di antaranya mendeskripsikan nilai-nilai yang terkandung dalam ritual tersebut ${ }^{7}$, uraian tentang makna simbolik dari rebo pungkasan, ${ }^{8}$ pergeseran makna yang hakiki dengan era saat ini, ${ }^{9}$ penggunaan ayat al-Quran dalam

${ }^{4}$ Sutrisna Wibawa, "Nilai Filosofi Jawa dalam Serat Centhini” Litera 12 (2), 2013: 328344. https://journal.uny.ac.id/index.php/litera/article/view/1546/1276. Lihat Endang Nurhayati, "Strategi Pemertahanan Bahasa Jawa di Provinsi Daerah Istimewa Yogyakarta" Litera 12 (1), 2013: 159-166. https://journal.uny.ac.id/index.php/litera/article/view/1338/1111. Lihat Burhan Nurgiyantoro, "Penggunaan Ungkapan Jawa dalam Kumpulan Puisi Tirta Kamandanu Karya Linus Suryadi (Pendekatan Stilistika Kultural)" Litera 13 (2), 2014: 201-214. https://journal.uny.ac.id/index.php/litera/article/view/2575/2129.

${ }^{5}$ Endang Setyaningsih dan Atiek Zahrulianingdyah, "Adat Budaya Siraman Pengantin Jawa Syarat Makna dan Filosofi" Teknobuga: Jurnal Teknologi Busana dan Boga 2 (2), 2015: 1-8. https://journal.unnes.ac.id/nju/index.php/teknobuga/article/view/6427/4885. Lihat Eko Setiawan, "Makna Filosofi Wayang Purwa dalam Lakon Dewa Ruci" Kontemplasi: Jurnal Ilmu-ilmu $\begin{array}{lllll}\text { Ushuluddin } & 5 & \text { (2), } & 2017 . & \text { http://ejournal.iain- }\end{array}$ tulungagung.ac.id/index.php/kon/article/view/870/606. Lihat J. Lukito Kartono, "Konsep Ruang Tradisional Jawa dalam Konteks Budaya" Dimensi Interior 3 (2), 2005: 124-136. http://dimensiinterior.petra.ac.id/index.php/int/article/view/16388/16380.

${ }^{6}$ Ada yang menyebutnya dengan Rebo Kasan atau Rebo Wekasan. Kendatipun begitu, maknanya tetap sama yakni ungkapan rasa syukur kepada Allah swt. yang lazim dilaksanakan masyarakat suku Jawa pada Rabu Akhir di Bulan Safar.

7 Purwa Prasetyaningrum, "Tradisi Rebo Pungkasan di Desa Lebaksiu Lor Kecamatan Lebaksiu Kabupaten Tegal” Sutasoma: Journal of Javanese Literature 4 (2), 2016. https://journal.unnes.ac.id/sju/index.php/sutasoma/article/view/29017.

${ }^{8}$ Rian Rahmawati, Zikri Fachrul Nurhadi, Novie Susanti Suseno, "Makna Simbolik Tradisi Rebo Kasan" Jurnal Penelitian Komunikasi 20 (1), 2017: 61-74. http://bppkibandung.id/index.php/jpk/article/download/131/191.

9 Ahmad Nurozi, "Rebo Wekasan dalam Ranah Sosial Keagamaan di Kabupaten Tegal Jawa Tengah (Analisis Terhadap Ritual Rebo Wekasan di Desa Sitanjung Lebaksiu” Prosiding Penelitian Seminar Nasional Seri 6: Menuju Masyarakat Madani dan Lestari. Yogyakarta, 30 November 2016, http://repository.wima.ac.id/9719/1/Prosiding\%20Seminar\%20Nasional $\% 20$ Seri $\% 206$ Penelit ian 2016.pdf\#page $=40$. 
ritualnya, ${ }^{10}$ bahkan riset tentang adanya indikasi pencitraan dalam tradisi tersebut. $^{11}$

Pemaknaan secara umum oleh masyarakat tentang rebo pungkasan sejatinya telah dipaparkan pada penelitian sebelumnya. Namun, pesan moral yang terkandung secara khusus bagi anak usia dasar belumlah tampak diperhatikan, padahal dalam studi pendahuluan ditemukan banyaknya sarana hiburan dan kuantitas (jumlah) anak yang hadir mengikuti upacara tersebut.

Berdasarkan hal di atas, peneliti ingin mengkaji lebih lanjut 'ruang kosong' tentang upacara adat rebo pungkasan dan pesan moral yang terkandung di dalamnya bagi anak usia dasar yang terangkum dalam judul Pesan Simbolik Lemper Raksasa dalam Upacara Adat Rebo Pungkasan bagi Anak Usia Dasar di Desa Wonokromo. Maka dari itu, rumusan masalah dalam penelitian ini mengkaji apa saja pesan moral dari lemper raksasa dalam upacara adat rebo pungkasan bagi anak usia dasar dan bagaimana pesan moral itu diberikan, serta bagaimana tradisi tersebut dilestarikan.

Penelitian ini dilakukan dengan mengamati dan menganalisa pesan moral yang terkandung dalam ritual budaya rebo pungkasan melalui lemper raksasa yang terdiri dari daun pisang (sebagai pembungkus), ketan dan daging cincang. Mencermati uraian di atas, secara sederhana kerangka alur metodologis riset ini dapat dilihat pada skema berikut. (Skema 1)

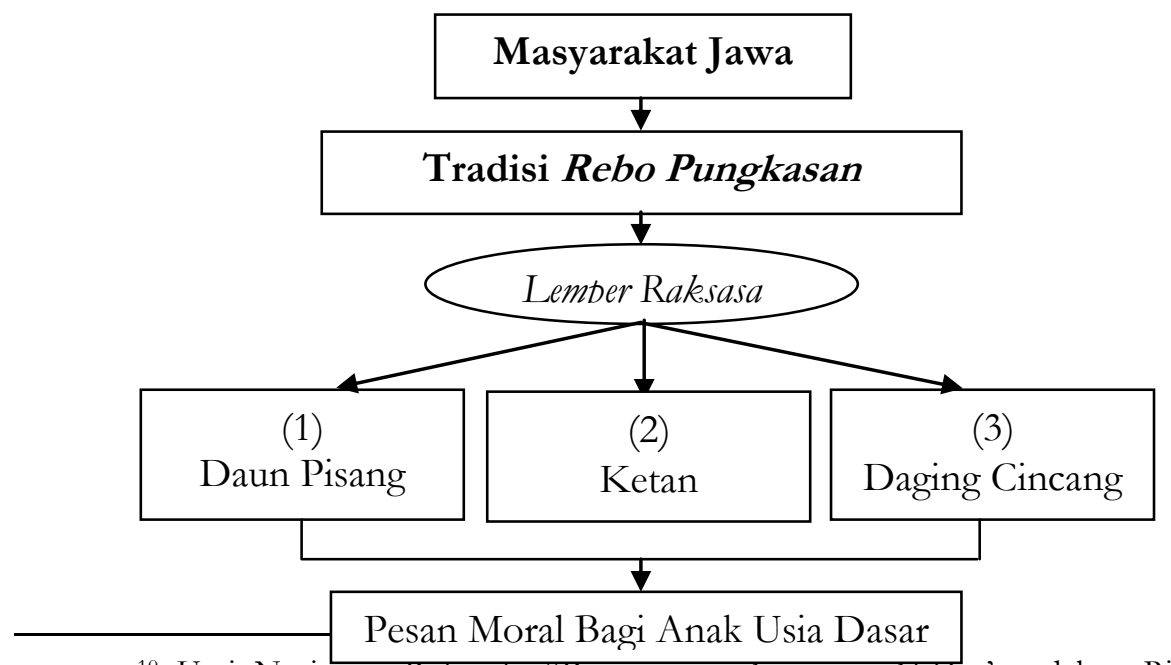

10 Umi Nuriyatur Rohmah, "Penggunaan Ayat-ayat AI-Qur'an dalam Ritual Rebo Wekasan: Studi Living Qur'an di Desa Sukoreno Kec. Kalisat Kab. Jember" Al-Bayan: Jurnal Imu al-Qur'an dan Hadis 1 (1), 2018: 67-91. http://ejournal.kopertais4.or.id/tapalkuda/index.php/albayan/article/view/3155/2342.

11 Galih Puspita Karti, "Indikasi Pencitraan dalam Upacara Adat Rebo Pungkasan di Wonokromo Pleret Bantul Yogyakarta" Invensi (Jurnal Penciptaan dan Pengkajian Seni) 1 (2), 2016: 13-23. http://journal.isi.ac.id/index.php/invensi/article/view/1612/410. 


\section{Skema 1. Alur Riset}

\section{Hasil dan Pembahasan}

\section{Sejarah Singkat Upacara Adat Rebo Pungkasan di Desa Wonokromo}

Upacara adat rebo pungkasan merupakan ritual kebudayaan yang secara turun-temurun dilaksanakan oleh masyarakat Desa Wonokromo. ${ }^{12}$ Keyakinan ini bermula dari Mbah Kyai Welit atau Kyai Faqih Usman atas jasanya di Desa Wonokromo $^{13}$ dan sekitarnya dalam menghindarkan masyarakat dari wabah penyakit.

Lazimnya, masyarakat menganggap bulan safar (bulan kedua dalam kalender hijriyah) 'rentan' datang wabah penyakit, untuk itu perlu dilaksanakan 'tolak bala' dengan bacaan yang diambil dari preskripsi al-Qur'an. Selanjutnya, ritual ini tidak sekadar diterapkan secara perorangan atas wabah penyakit yang menimpa, melainkan dibudayakan oleh masyarakat sebagai ungkapan rasa syukur kepada Allah swt.

Desa Wonokromo sendiri awalnya merupakan hutan yang dikenal dengan istilah alas awar-awar, Kyai Faqih Usman yang kala itu diamanahkan sebagai Pathok Negoro oleh Sri Sultan Hamengkubowono I, berinisiatif untuk mendirikan masjid bersama masyarakat yang diberi nama Masjid Wa Anna Karoma berarti benar-benar mulya. Singkatnya, daerah tersebutlah yang kini lebih dikenal dengan nama Wonokromo.

Upacara kata rebo pungkasan berasal dari kata "(hari) Rabu" dan "akhir (dalam bahasa Jawa disebut pungkasan)". Ini menunjukkan bahwa ritual ini dilaksanakan setiap hari Rabu terakhir dalam bulan safar yang dalam lisan Jawa lebih mudah disebut Sapar.

Prosesi ritual rebo pungkasan diawali dengan membaca doa bersama yang dipimpin ketua adat, selanjutnya rombongan (atau kirab) pawai dengan mengarak lemper raksasa, kemudian rayahan (makan bersama makanan yang telah 'disucikan' dengan doa selama sehari sebelum upacara), dan diakhiri doa bersama di Masjid Karanganom Wonokromo.

12 Galih Puspita Karti, "Indikasi Pencitraan dalam Upacara Adat Rebo Pungkasan di Wonokromo Pleret Bantul Yogyakarta" Invensi (Jurnal Penciptaan dan Pengkajian Seni) 1 (2), 2016: 13-23. http://journal.isi.ac.id/index.php/invensi/article/view/1612/410.

13 R. Aris Hidayat, "Masjid Sebagai Pelestari Tradisi: Kajian Fungsi Masjid Wonokromo Bantul Yogyakarta dalam Perspektif Historis" Jurnal Analisa 18 (2), 2011: 228-246. https://blasemarang.kemenag.go.id/journal/index.php/analisa/article/view/135/90. 
Adapun dalam pelaksanaannya, para rombongan membaca doa-doa yang dengannya mengharap berkah dari Allah swt., meliputi bacaan surah al-Fatihah, Yasin, wiridan, doa sapu jagad, serta doa maulidan (sebab berdekatan dengan maulid Nabi Mubammad saw).

\section{Makna Simbolik Lemper Raksasa dalam Upacara Adat Rebo Pungkasan}

Lemper Raksasa merupakan simbolik makanan yang diarak bersama ketika pawai upacara adat rebo pungkasan. ${ }^{14}$ Sejatinya, lemper ialah makanan berisikan daging cincang dan ketan yang dibungkus dengan daun pisang. Ketiga komposisi lemper tersebut ternyata mengandung pesan moral bagi anak usia dasar yang oleh masyarakat dijadikan sebagai simbolik yang patut dipersembahkan pada Allah swt. sebagai ungkapan rasa syukur.

Adapun pesan moral dalam tiga komposisi lemper tersebut diuraikan sebagai berikut:

\section{Kulit Luar Daun Pisang}

Daun pisang merupakan bagian terluar dari lemper. Sebagai penutup bungkus makanan yang satu ini, daun pisang berfungsi untuk menjaga sisi dalam makanan dari hal-hal yang dapat mengotorinya. Sehingga, bagian isi dalam lemper tetap terjaga untuk diberikan kepada orang lain maupun dimakan bersama.

Alasan utama daun pisang dipilih sebagai alat bungkus lemper karena mudah dijumpai di Desa Wonokromo, tahan lama, tidak merusak makanan dan cukup ekonomis. Hal ini sesuai dengan penuturan salah satu warga Desa Wonokromo yakni Ibu ida, "inggih leres mbak Ika. Neng kene iku, nek arep gawe lemper yo nganggo dong pisang, neng ngendi wae yo panggah godong pisang. Mergane, nek nggae godong pisang lempere luweh terjaga, ga nggoh pengawet toh. Selain iku, yo mergo murah, ra sah tuku larang, iso jaluk. tanggane."

Bila diterjemahkan secara "bebas" maknanya berikut ini, "Di sini kita man bungkus lemper pakai daun pisang, babkan di mana-mana juga sama pake daun pisang. Karena isi lemper-nya tetap terjaga, ga pake pengawet toh daun pisangnya. Selain itu, yo murah, bahkan kadang-kadang ga beli pun, saya minta ke tetangga."

Bila dimaknai, lemper diibaratkan sebagai suatu kesatuan hidup yang utuh, punya sisi luar dalam hidup berupa 'daun pisang'. Ini menunjukkan bahwa

${ }^{14}$ Galih Puspita Karti, "Indikasi Pencitraan dalam Upacara Adat Rebo Pungkasan di Wonokromo Pleret Bantul Yogyakarta" Invensi (Jurnal Penciptaan dan Pengkajian Seni) 1 (2), 2016: 13-23. http://iournal.isi.ac.id/index.php/invensi/article/view/1612/410.

${ }^{15}$ Wawancara dengan Ibu Ida, salah satu warga Desa Wonokromo yang ikut dalam acara rebo pungkasan, pada 26 November 2019, pukul 18.00 WIB, di Desa Wonokromo I. 
manusia sebagai satu kesatuan individu yang senantiasa 'diselimuti' berbagai rintangan dan masalah.

Lantas timbul pertanyaan? Apakah dengan diibaratkannya 'daun pisang' yang menutupi isi dalam lemper sebagai suatu rintangan atau masalah menjadikan orang yang hendak memakan lemper menghindarinya? kemudian tidak mencoba untuk membukanya? Tentu jawabannya tidak. Sebab, si pemakan lemper pasti berupaya membuka 'daun pisang' agar dapat menyantap nikmatnya isi lemper, meskipun harus menyita waktu untuk membukanya.

Selanjutnya, analogi di atas didekatkan pada kehidupan yang dijalani manusia. Maka, masalah dan berbagai rintangan kehidupan bukanlah sesuatu yang patut dihindari, sebab dengan menghindarinya bukan malah menemukan kenikmatan hidup. Untuk itu, permasalahan dipandang semata sebagai 'daun pisang' yang ada pada lemper. Suka tidak suka, isi lemper yang ingin dimakan, harus melalui upaya membuka bungkusnya. Sehingga, kenikmatan dalam hidup akan diperoleh bagi orang yang siap untuk melalui rintangan dan masalah yang secara utuh satu kesatuan mengiringi kehidupan seseorang.

Hal ini sebagaimana yang diungkapkan Slamet ketika diwawancarai, "Bungkusnya ini sengaja kita pakai daun pisang karena mudah dicari dan murah mbak. Kalau dalam upacara ini, bungkusannya kita anggap kayak hidup seseorang yang dibungkusi banyak masalah, sehingga tidak tahu apa isi dibaliknya itu. Jadi, masyarakat dan kita semua dengan ini sadar, bahwa ada kebaikan dibalik yang Allah berikan itu semuanya, maka jangan lupa bersyukur hari ini, dan setiap harinya. Itu sib hikmah dari ini mbak."

Begitupun, rasa syukur menjadi perhatian penting dalam hal ini. Sebab, Allah swt. sebagai pencipta makhluk (manusia dan lainnya), 'sengaja' memberikan manusia berbagai rintangan kehidupan sesuai kadar kemampuan hamba-Nya. Hanya saja, menyikapi secara arif atas permasalahan yang ada akan menghadirkan nikmatnya hidup bagi individu, baik secara lahiriah maupun batiniah.

\section{Ketan}

Ketan merupakan isi terluar dari lemper, terbuat dari beras yang tentunya mengandung karbohidrat tinggi. Bagian ini sudah bisa dikonsumsi dan dirasakan nikmatnya, hanya saja masih terdapat bagian inti dari lemper yang akan dijelaskan pada poin 3 berupa 'daging cincang'.

${ }^{16}$ Wawancara dengan Bapak Slamet, Pemuka Adat Desa Wonokromo, 26 Oktober 2019, pukul 17.00 WIB, dusun Wonokromo I. 
Ketan menurut masyarakat setempat, dianalogikan sebagai suatu kenikmatan yang diperoleh si pemakan lemper usai membuka bungkusan luarnya berupa daun pisang. Hal ini dimaknai sebagai hasil dari sebuah usaha yang didapati seseorang usai berjuang hebat, pantang menyerah dan siap menghadapi berbagai rintangan serta permasalahan kehidupan.

Hal ini senada dengan yang disampaikan Slamet berikut, "ketan ini udah bisa dimakan toh mbak. Tapi, kalau kita makan lemper jangan cepat-cepat puas sampai ketan saja, sebab masih ada lagi isi dalamnya berupa daging. Melalui ritual ini, kita dari pemuka adat ngajak masyarakat untuk kembali memahami budaya kita sekaligus paham bahwa usaha tadi buka bungkus 'daun pisang' sudah bisa memakan ketan, dan ingat juga kenikmatan masih ada lagi di bagian dalam, jadi jangan cepat puas kalau dapat sesuatu, terus belajar, belajar dan ambil hikmahnya." $" 17$

Kenikmatan yang dirasakan merupakan karunia dari Allah swt. Sehingga, rasa syukur menjadi suatu keniscayaan yang dihadirkan dalam diri seseorang untuk lebih mendekatkan diri kepada Allah swt., meningkatkan kualitas dan kuantitas keimanan dengan melaksanakan ibadah sebagai pengabdian pada-Nya. Hal ini didasari atas kesadaran bahwa ujian awal (masalah yang dianalogikan seperti 'daun pisang'---bungkus lemper---) bermuara pada kenikmatan bagi yang menyikapi dengan penuh prasangka baik pada Allah swt.

\section{Daging Cincang}

Bagian inti dari makanan lemper ialah daging cincang. Ini merupakan daging ayam yang digoreng dan diselubungi ketan serta daun pisang sebagai pembungkusnya. Kelezatan pada bagian ini tentu menambahkan cita rasa dari lemper. Sehingga, lengkaplah kenikmatan yang diperoleh seseorang yang memakannya.

Masyarakat Desa Wonokromo menganalogikan 'daging cincang' sebagai inti kenikmatan lemper. Usai dibuka bungkusnya (daun pisang), ketan menjadi rasa pembuka, dilanjutkan bagian 'daging cincang' menjadikan 'sempurna' nikmatnya makanan bernama lemper.

Pemaknaan 'daging cincang' ini dipandang sebagai hasil usaha atas 'jerihpayah' seseorang. Bukan hanya kenikmatan duniawi semata, melainkan adanya ghirah menuju bekal akhirat yang diajarkan melalui makanan lemper ini. Di mana masyarakat menganggap bahwa lemper pada bagian 'daging cincang' sebagai simbolik kenikmatan yang hakiki untuk kehidupan dunia dan akhirat, dengan melalui berbagai rintangan dan masalah.

${ }^{17}$ Wawancara dengan Pak Slamet, Pemuka Adat Desa Wonokromo, 26 Oktober 2016, pukul 17.00 WIB, di Desa Wonokromo I. 
Sehingga upaya mengedepankan syukur dan mengalahkan hawa nafsu menjadi titik fokus yang disampaikan pemuka adat Jawa Desa Wonokromo ketika diwawancarai, "Masyarakat desa kita ini, menganggap bagian daging cincang sebagai hasil atas upaya mengalahkan hawa nafsu dari godaan luar hidup yang ada dibungkus daun dan ketan. Untuk melalui itu, pasti tidak mudah, maka bersyukur selalu kepada Allah dan menginstropeksi diri dari lemper ini mudahmudahan selalu mendatangkan barokah dan hidayah dari Allah kepada kita mbak.","

Dari sisi lain, Ida juga menuturkan betapa 'daging cincang' yang sedikit secara ekonomis lebih mahal dari ketan dan daun yang membungkusnya. Berikut kutipan wawancaranya, "iya mbak, daging cincang ini nampaknya saja yang dikit, padahal kalau kita mau hitung yang paling mahal itu bagian daging, bukan bagian ketan sama bungkusnya. Maka, wajarlah dalam hidup ini intinya itu yang paling nikmat, maka jangan bosan terus berusaha sebab ada nikmat yang Allah titipkan dari berbagai bungkusan masalah hidup ini. toh mbak nya sendiri tahu, bahwa mutiara itu adanya di dasar laut, bukan permukaan laut toh?" 19

Kutipan wawancara di atas menunjukkan bahwa rasa syukur dan penghargaan atas suatu usaha menjadi titik poin penting bagi masyarakat Desa Wonokromo. Kesadaran yang timbul atas ketidakmampuan memahami hikmah dibalik suatu permasalahan, juga menjadi landasan agar masyarakat senantiasa berharap berkah dan hidayah dari Allah swt.

\section{Pesan Moral Lemper Raksasa dalam Upacara Adat Rebo Pungkasan Bagi Anak}

Sebuah tradisi yang membudaya senantiasa diajarkan kepada generasi muda, sebagai pelanjut estafet kehidupan bermasyarakat serta ditujukan agar anak muda memahami esensi dan proses pelaksanaan dari ritual budayanya. ${ }^{20}$ Hal ini merupakan upaya melestarikan suatu budaya agar tidak tercabut akar genealogisnya.

Upacara adat rebo pungkasan sebagai tradisi tahunan yang dilaksanakan masyarakat suku Jawa di Desa Wonokromo menampilkan lemper raksasa sebagai

18 Wawancara dengan Pak Slamet, Pemuka Adat Desa Setempat (Desa Wonokromo, Pleret, Bantul, DIY), 26 Oktober 2019, pukul 17.00 WIB.di desa Wonokromo I.

${ }^{19}$ Wawancara dengan Bu ida, Warga Desa Wonokromo yang juga merupakan warga di desa Wonokromo, 26 November 2019, pukul 18.00 WIB, di Desa Wonokromo II.

20 Maman Rachman, "Konservasi Nilai dan Warisan Budaya" Indonesian Journal of $\begin{array}{lllll}\text { Conservation } & 1 & (1), & 2012: & 30-39 .\end{array}$ https://journal.unnes.ac.id/nju/index.php/ijc/article/view/2062/2176. Lihat M. Nadlir, "Urgensi Pembelajaran Berbasis Kearifan Lokal" Jurnal Pendidikan Agama Islam 2 (2), 2016: 299330. http://jurnalpai.uinsby.ac.id/index.php/jurnalpai/article/view/33. 
‘ikon' yang diarak oleh warga yang berbusana lengkap bak prajurit keraton kerajaan yang dikenal dengan istilah bregodo ${ }^{21}$.

Iringan warga yang menyaksikan diarak-araknya lemper raksasa bukan hanya dari kalangan orang dewasa, orangtua, atau sesepub desa tersebut, melainkan juga dihadiri oleh kalangan muda bahkan anak-anak kecil. Hal ini dalam satu sisi menunjukkan antusias warga, sedang di sisi lain menunjukkan betapa pentingnya mengajarkan budaya kepada anak muda bahkan anak kecil sejak usia dasar.

Lemper raksasa sebagai ikon yang ditampilkan memiliki pesan moral secara simbolik kepada anak dalam konteks pendidikan. Adapun pesan moral tersebut terbagi kepada 3 (tiga) aspek meliputi; (1) daun pisang sebagai tampilan masalah dalam belajar, (2) ketan sebagai kenikmatan dalam belajar dan (3) daging cincang sebagai simbol bahwa belajar merupakan bekal kehidupan.

Hal ini seperti dituturkan Kholiq ketika ditemui di lokasi upacara adat rebo pungkasan: "anak-anak sengaja kita diajak oleh orangtua masing-masing, supaya mereka belajar dan mencintai adat budaya orangtua kita terdahulu (leluhur). Misal dari lemper raksasa yang diarak-arak tadi, ada pesan moralnya itu untuk anak-anak kecil, mulai dari daun pisang, ketannya, sampai isi dalamnya daging cincang. Apalagi sekarang acara rebo pungkasan sudah banyak hiburannya untuk anak-anak, seperti perlombaan dan pertunjukkan, adapula hadroh, pengajian akbar, shalawatan.",22

\section{'Daun Pisang' Pembungkus Lemper Sebagai Simbol Masalah dalam Belajar}

'Pendidikan akarnya pahit buahnya manis' slogan yang menganalogikan pendidikan bak ibarat sebuah pohon, di mana prosesnya digambarkan seperti 'akarnya pohon yang pahit' dan hasil dari menempuh pendidikan seperti 'buah yang manis'. Di dinding beberapa lembaga pendidikan juga terpampang tulisan 'dengan ilmu hidup jadi mudah'. Ini menunjukkan bahwa ilmu sebagai hasil yang diperoleh seseorang usai menempuh pendidikan akan membantu kemudahan hidupnya.

Begitupun, pendidikan ditempuh bukan dengan tanpa tantangan dan rintangannya. Berbagai masalah kerap ditemui para penuntut ilmu selama proses belajar, baik permasalahan biaya, 'kesulitan belajar', butuh waktu lama dan sebagainya.

\footnotetext{
${ }^{21}$ Pasukan prajurit keraton dengan pakaian lengkapnya, yang lazim bertugas mengiringi dan mengawal arak-arakan acara Keraton.

22 Wawancara dengan Pak Kholiq, Pemuka Adat Desa Setempat (Desa Wonokromo, Pleret, Bantul, DIY), 22 oktober 2019,pukul 21.00 WIB, di halaman Pendapa desa Wonokromo.
} 
Permasalahan ini timbul dan mengiringi proses belajar seseorang kerap dipandang sebagai rintangan yang 'berat' dan masalah 'besar'. Ada yang mampu menyikapinya dengan baik bahkan berani menghadapinya, meskipun adapula yang 'menyerah' dengan menghindari masalah yang ada.

Upacara adat rebo pungkasan menampilkan lemper raksasa sebagai ikon simbolik yang mengandung banyak pesan moral, termasuk khusus ditujukan kepada anak usia dasar. Dalam hal ini 'daun pisang' yang digunakan sebagai pembungkus lemper bermakna sebagai masalah yang hadir di hadapan awal seseorang, padahal ada kenikmatan yang ada pada sisi dalam lemper.

Pesan moral dari 'daun pisang' ini bagi anak usia dasar terletak pada proses belajar yang ditempuhnya. Kerap kali anak mengeluhkan banyaknya tugas rumah -Pekerjaan Rumah/PR--, sulitnya belajar, bahkan tidak jarang menyita waktu bermain anak. Hal ini tentu menjadi polemik tersendiri bagi anak usia dasar yang masih pada fase bermain.

Nasihat dan gambaran kesuksesan orang-orang terdahulu yang lebih awal melalui pendidikan adalah salah satu upaya yang lazim dilakukan orangtua untuk menunjukkan pada anak bahwa 'manisnya' hasil dari belajar, hanya prosesnya yang seolah-olah sulit untuk dilalui. Begitu juga dengan 'daun pisang' yang ada pada lemper, tampaknya dari luar hanya bungkusan dari daun pisang, padahal isi di dalamnya ada 'ketan' dan 'daging cincang'.

Hal ini seperti dituturkan Kholiq ketika ditemui di lokasi upacara adat rebo pungkasan: "daun pisang itu ibaratnya masalah belajar bagi anak-anak di sekolahan. Nampaknya sulit, pun kalau dimakan rasanya daun pisang yo ora penak. Belajar juga gitu, mau di-enak-enakin juga yo gimana enaknya mbak. Orangtua sulit cari biaya sekolah, anak-anak juga banyak tugas. Mesti dinikmatilah mbak, supaya berkah dan maunya kan anak-anak bisa sukses semua." 23

Uraian di atas menunjukkan alasan orangtua Desa Wonokromo berbondong-bondong mengajak anak-anaknya untuk ikutserta menyaksikan upacara adat rebo pungkasan secara langsung. Selain anak-anak dapat terhibur melalui sarana hiburan yang ada, terpenting anak-anak 'disuguhi' nasihat melalui simbol lemper raksasa bagi pendidikan mereka.

\section{Ketan Lemper Sebagai Simbol Kenikmatan dalam Belajar}

Kenikmatan belajar itu sejatinya terletak pada prosesnya, bukan sematamata pada hasil. Anak-anak sejak usia dasar dididik untuk memperoleh bekal

${ }^{23}$ Wawancara dengan Pak Kholiq, Pemuka Adat Desa Setempat (Desa Wonokromo, Pleret, Bantul, DIY), 22 Oktober 2019,pukul 21.00 WIB, di halaman pendapa desa Wonokromo. 
dan kesiapan serta kematangan diri dalam bermasyarakat. Hal ini merupakan tuntutan bagi setiap individu sebagai makhluk sosial.

Kehidupan bermasyarakat yang dihadapi anak, tentu berbeda dengan zaman orangtuanya. Hal ini didorong atas kemajuan teknologi serta berbagai kecanggihan yang ada, menjadikan anak harus matang intelektual, emosional dan terpenting spiritual. Ketiga komponen inilah yang diasah, diasih serta diasuh bagi anak selama menjalani proses pendidikan, baik di lingkungan keluarga, masyarakat maupun sekolah atau madrasah.

Upacara adat rebo pungkasan dengan melibatkan anak ikutserta menyaksikan ritual budaya tersebut, juga menyajikan pesan moral kepada anak berupa 'ketan' yang ada dalam lemper. Kendatipun yang diarak-arak oleh masyarakat adalah replika lemper raksasa.

Ketan sendiri dimaknai oleh masyarakat sebagai kenikmatan awal yang diperoleh setelah melalui bungkusan daun pisang pada lemper. Hal ini dididikkan kepada anak, bahwa pendidikan sejatinya memberikan kenikmatan tersendiri bagi setiap orang yang belajar. Maka dari itu, anak diberikan pesan moral, betapa ketan yang awalnya tidak tampak saat dibungkus oleh daun pisang. Setelah dibuka ternyata memiliki rasa nikmat yang tak terpikirkan.

Untuk itu, anak-anak diminta semangat dan rajin belajar. Tidak mengenal mesti dari kota maupun keluarga berkecukupan. Tekad dan kemauan akan mengantarkan pada kenikmatan awal belajar yang disimbolkan pada ketan dalam lemper.

Hal ini senada dengan penuturan Slamet: “iya mbak, anak-anak kan belum tahu untuk apa sih guna mereka belajar. Jadi pas diajak ikut menyaksikan rebo pungkasan dan melihat sendiri langsung lemper, kita sampaikan kepada anak nasihat bahwa belajar nampaknya saja yang agak sulit seperti dilihat lemper dari luar, ya cuman daun pisang. Tapi kalau sudah sedikit terbuka, maka ketannya enak, bisa mengeyangkan dan terasa nikmat. Begitulah anak-anak kita ajarkan secara langsung mengambil nasihat dari budaya yang kita jaga bersama." 24

Kutipan wawancara di atas menunjukkan bahwa masyarakat Desa Wonokromo menjadikan budaya sebagai salah satu cara mendidik anak secara lokal. Sebab, budaya dekat dengan anak di daerahnya, sehingga pesan moral yang disampaikan akan lebih mengena pada anak sejak usia dasar.

\section{Daging Cincang Lemper Sebagai Simbol bahwa Belajar Bekal Kehidupan}

${ }^{24}$ Wawancara dengan Pak Slamet, Pemuka Adat Desa Setempat (Desa Wonokromo, Pleret, Bantul, DIY), 26 Oktober 2019, pukul 17.00 WIB, di Desa Wonokromo I. 
Daging cincang merupakan isi bagian terdalam lemper. Ia digunakan sebagai simbolik kenikmatan yang terbungkus dalam lemper setelah melalui 'daun pisang' dan 'ketan'. Dari sisi ekonomis, daging cincang adalah yang paling sedikit kuantitasnya pada komposisi lemper, namun juga paling mahal. Senada dengan yang disampaikan Kholiq: "lemper kan ada bungkusnya (daun pisang), isinya ada ketan sama daging cincang. Paling dikit itu yo daging cincangnya mbak, tapi yang paling mahal juga daging cincang. Selain itu, tempatnya bagian paling dalam. Jadi kelihatan toh, yang paling berharga itu bagian terdalamnya." 25

Selain itu, masyarakat juga menginternalisasikan pesan moral kepada anak melalui simbolik 'daging cincang' pada lemper. Adapun yang diberikan kepada anak yakni bahwa semakin mendalami belajar, maka akan semakin merasakan nikmatnya belajar. Hal ini senada dengan ungkapan dari seorang Bapak yang ikut langsung dalam upacara adat rebo pungkasan: "iya mbak, anakanak saya itu senang diajak ke sini. Apalagi kalau lihat lemper raksasa lemper raksasa, mereka pasti gembira. Tapi itukan hanya replika saja mbak. Karena, ada pesan moral dari lemper buat masyarakat di sini, dan juga senantiasa kami ajarkan kepada anak kecil. Misalnya daging cincang, itukan punya pesan bahwa anak harus belajar sejak kecil, karena semakin lama, semakin mendalami belajar, maka anak semakin merasakan nikmatnya belajar itu sendiri. Tentu ini tidak mudah, yang penting saat ini ada diminta terus dan tetap sabar belajar, toh nantinya mereka akan paham sendiri nikmatnya belajar serta menjadikan belajar sebagai upaya mencari berkah kehidupan mereka." ${ }^{26}$

Kutipan di atas senada dengan ungkapan yang pernah disampaikan Ali bin Abi Thalib, "Yakinlah, ada sesuatu yang menantimu setelab banyak, kesabaran (yang kau jalani), yang akan membuatmu terpana hingga kau lupa betapa pedibnya rasa sakit." Untuk itu, peran orangtua dalam menginternalisasikan nilai-nilai yang ada dalam rebo pungkasan khususnya simbolik lemper raksasa, sangat mengedukasi anak untuk mencintai budaya dan memahami makna dari budaya yang dicintainya.

\section{Melestarikan Rebo Pungkasan di Desa Wonokromo}

\section{Sarana Hiburan}

Rebo pungkasan era saat ini dilaksanakan dengan membentuk kepanitiaan yang menyusun kerangka acara dan berbagai sarana hiburan untuk memeriahkan ritual tahunan di Desa Wonokromo Kecamatan Pleret Kabupaten Bantul- DI. Yogyakarta.

${ }^{25}$ Wawancara dengan Pak Kholiq, Warga Desa Setempat (Desa Wonokromo, Pleret, Bantul, DIY), 22 Oktober 2019, pukul 21.00 WIB

${ }^{26}$ Wawancara dengan Pak Kholiq, Warga Desa Setempat (Desa Wonokromo, Pleret, Bantul, DIY), 22 Oktober 2019, pukul 21.00 WIB, di halaman pendapa balai Desa Wonokromo. 
Adapun sarana hiburan yang disajikan berupa perlombaan, pertunjukkan ritual budaya dan permainan. Kegiatan tersebut dilaksanakan tepat seminggu sebelum upacara. Hal ini ditujukan untuk mengundang antusiasme masyarakat dalam menyambut upacara adat rebo pungkasan.

Sarana hiburan ini juga ditujukan sebagai upaya melestarikan budaya di Desa Wonokromo sehingga masyarakat tetap antusias datang, dengan tujuan utama tetap mengungkapkan rasa syukur kepada Allah swt. hal ini sebagaimana disampaikan Bapak Dani, Kepala Dusun Wonokromo II ketika ditemui di kediamannya

"Untuk sekarang ini, zaman sudah makin maju. Jadi kalau budaya ditampilkan seperti biasa, bisa jadi yang hadir orangtua saja mbak. Maka, kita badirkan acara-acara yang juga bisa mengundang anak-anak muda, anak-anak kecil untuk datang ke rebo pungkasan ini, walau awalnya kita libat di kegiatan rebo pungkasan kemarin toh mbak, anak-anak itu lebih banyak beli jajanan, menikmati pasar malam, main wahana yang ada, terpenting mereka ikut dulu. Nanti pelan-pelan mereka paham apa pentingnya budaya kita ini, dan saya sebagai kepala desa ingin budaya-budaya yang ada di Desa Wonokromo ini tetap dilestarikan terus oleh generasi-generasi muda." ${ }^{27}$

Kutipan wawancara di atas menegaskan bahwa sarana hiburan diselenggarakan kepanitiaan rebo pungkasan dengan tujuan upaya melestarikan budaya masyarakat Jawa di Desa Wonokromo tersebut. Sehingga, generasi muda yang awalnya 'mungkin' ikutserta karena ada wahana permainan dan sarana hiburan, beralih menjadi cinta dan menyenangi budaya leluhur secara turuntemurun.

\section{Aset Pariwisata}

Sarana hiburan yang disemarakkan pula dengan berbagai wahana permainan dalam acara rebo pungkasan di Desa Wonokromo, seiring waktu ternyata menarik perhatian masyarakat luar desa tersebut. Animo masyarakat ditunjukkan dengan banyaknya pengunjung lokal luar desa Wonokromo yang sengaja hadir menyaksikan ritual kebudayaan tersebut serta hadir pula pengunjung asing (foreign tourism).

Berikut beberapa tanggapan pengunjung yang menyaksikan langsung kegiatan tersebut:

Pengunjung dari desa Bawuran, "Kegiatan ini awalnya kami tahu dari keluarga yang tinggal di Wonokromo, karena pas lagi liburan dan ke sini, ya langsung ikut karena juga penasaran dengan kegiatannya. Alhasil, setelah lihat langsung kegiatannya menarik, ada hiburan untuk anak dan juga ada shalawatan,

${ }^{27}$ Wawancara dengan Pak Dani Kepala Dusun Wonokromo II, Pleret, Bantul, DIY, 23 November 2019, pukul 19.00 WIB,di desa Wonokromo II. 
pengajian akbar dan hadroh. Bahkan sebelumnya ternyata ada juga lomba untuk masyarakat setempat. Memang betul-betul meriah. Wajarlah kegiatan ini bisa terus ada, karena budayanya tetap terjaga dan masyarakat mengemasnya dengan unik." 28

Pengunjung dari luar negeri (Australia): "We happened to be recreation to Yogyakarta, had begined to Malioboro Street, various temples and beaches in Yogyakarta. From our friends who have been here, we heard there is a unique activity here. This afternoon, we set out to come and see firsthand. As it turned out, this activity was indeed very unique, there were performing Javanese arts and cultures, the community enthusiastic, and we the newcomers were happy to join this event, plus the citizens are friendly." ${ }^{, 29}$

Bila diterjemahkan secara "bebas" dapat dimaknai sebagai berikut: "Kami kebetulan sedang rekreasi ke Yogyakarta, kami sudah main ke Malioboro, berbagai candi dan pantai yang ada di Yogyakarta. Selanjutnya, dari teman kami yang sudah pernah ke sini, kami mendengar ada kegiatan unik di sini. Sore tadi kami berangkat untuk datang, dan melihat langsung. Ternyata, kegiatan ini memang sangat unik, ada tampil seni budaya Jawa, masyarakat antusias, dan kami pun pendatang senang sekali ikut acara ini, ditambah lagi masyarakatnya yang ramah-tamah.”

Berdasarkan uraian di atas, jelas bahwa upacara adat rebo pungkasan disenangi oleh masyarakat luas, bahkan animo masyarakat yang hadir menambah daya semangat pihak penyelenggara kegiatan. Seperti yang diungkapkan Pak fulan yang menyampaikan harapnya, "...semoga badirnya pengunjung lokal dan asing bisa menjadi semangat tersendiri bagi kami panitia, ditambah lagi bisa semakin mengenalkan dan melestarikan budaya rebo pungkasan di Desa kami". ${ }^{30}$ Sebab, tidak hanya pengunjung yang datang dari lokal, pengunjung asing asal luar negeri juga mengaku senang menyaksikan kegiatan tersebut.

\section{Media Silaturahmi}

Upacara rebo pungkasan, selain menghadirkan sarana hiburan, aset pariwisata dan wahana permainan juga merupakan media silaturahmi bagi masyarakat setempat. Sehingga tidak sedikit dari warga menjadikan ini

${ }^{28}$ Wawancara dengan Bu Siti, Pengunjung yang hadir dari desa Bawuran menyaksikan langsung kegiatan upacara rebo pungkasan di Desa Wonokromo, 22 Oktober 2019,pukul 19.00 WIB.di lapangan desa jejeran.

29 Wawancara dengan Thomas Anderson, Pengunjung yang hadir dari Australia menyaksikan langsung kegiatan upacara rebo pungkasan di Desa Wonokromo, 22 Oktober 2019,pukul 19.00 WIB, di lapangan desa Jejeran.

30 Wawancara dengan Rina, panitia pelaksana kegiatan upacara rebo pungkasan di Desa Wonokromo, 22 Oktober 2019, pukul 19.00 WIB, di lapangan Jejeran. 
momentum saling bertemu, bercengkerama, bertatap muka dan menjadi ajang untuk mempererat silaturahmi.

\section{Sarana Integrasi Sosial}

Apabila dikatakan kebudayaan merupakan ajang integrasi bangsa, memang benar adanya. Karena kebudayaan merupakan hasil cipta karsa manusia yang berpadu, yang merupakan hasil buah pikiran manusia. Alasan kedua adalah bahwa kebudayaan merupakan suatu integritas adalah karena unsur-unsur kebudayaan bertentangan dengan yang lain, sehingga tidak mustahil untuk bersama-sama mempertahankan yang bertentangan itu. Jadi, kebudayaan cenderung terdiri dari unsur-unsur yang berbeda dan dipadukan menjadi suatu keselarasan sehingga tercipta integrasi.

\section{Penutup}

Berdasarkan hasil penelitian di atas, disimpulkan bahwa (1) lemper raksasa bernilai pesan moral secara simbolik kepada anak usia dasar, berupa daun pisang sebagai simbol 'masalah' belajar anak, ketan sebagai simbol 'kenikmatan awal' belajar anak dan daging cincang sebagai simbol belajar menjadi 'bekal kehidupan' anak; (2) pesan moral simbolik itu diberikan kepada anak dengan mengajak anak menyaksikan langsung rebo pungkasan dan menginternalisasikannya secara lisan kepada anak masing-masing; (3) untuk melestarikan budaya tersebut, maka difungsikan sebagai sarana hiburan, aset pariwisata, media silaturahmi dan sarana integrasi sosial.

\section{Bibliografy}

Hidayat, R. Aris. (2011). "Masjid Sebagai Pelestari Tradisi: Kajian Fungsi Masjid Wonokromo Bantul Yogyakarta dalam Perspektif Historis" Jurnal Analisa 18

https://blasemarang.kemenag.go.id/journal/index.php/analisa/article/vi ew/135/90.

Iskandar, Dadan. (2004). "Identitas Budaya dalam Komunikasi Antar-Budaya: Kasus Etnik Madura dan Etnik Dayak" Jurnal Masyarakat dan Budaya 6 (2): 119-140. http://jmb.lipi.go.id/index.php/jmb/article/view/208/188.

Karti, Galih Puspita. (2016). "Indikasi Pencitraan dalam Upacara Adat Rebo Pungkasan di Wonokromo Pleret Bantul Yogyakarta" Invensi (Jurnal Penciptaan dan Pengkajian Seni) 1 (2): 13-23. http://journal.isi.ac.id/index.php/invensi/article/view/1612/410. 
Ika Damayanti, M. Shaleh A.\& Izzatin Kamala: Pesan Moral dan Nilai Pendidikan... | 357

Kartono, J. Lukito. (2005). "Konsep Ruang Tradisional Jawa dalam Konteks Budaya" Dimensi Interior $3 \quad$ (2): $124-136$. http://dimensiinterior.petra.ac.id/index.php/int/article/view/16388/163 $\underline{80}$.

Koentjaraningrat. (1990). Metode-metode Antropologi dalam penyelidikan Masyarakat dan Kebudayaan Indonesia, (Jakarta: UI Press).

Nadlir, M. (2016). "Urgensi Pembelajaran Berbasis Kearifan Lokal" Jurnal Pendidikan Agama Islam 2 (2): 299-330. http://jurnalpai.uinsby.ac.id/index.php/jurnalpai/article/view/33.

Nurgiyantoro, Burhan. (2014). "Penggunaan Ungkapan Jawa dalam Kumpulan Puisi Tirta Kamandanu Karya Linus Suryadi (Pendekatan Stilistika Kultural)" $\quad$ Litera $13 \quad$ (2): $201-214$. https://journal.uny.ac.id/index.php/litera/article/view/2575/2129.

Nurhayati, Endang. (2013). "Strategi Pemertahanan Bahasa Jawa di Provinsi Daerah Istimewa Yogyakarta" Litera 12 (1): 159-166. https://journal.uny.ac.id/index.php/litera/article/view/1338/1111.

Nurozi, Ahmad. (2016). "Rebo Wekasan dalam Ranah Sosial Keagamaan di Kabupaten Tegal Jawa Tengah (Analisis Terhadap Ritual Rebo Wekasan di Desa Sitanjung Lebaksiu" Prosiding Penelitian Seminar Nasional Seri 6: Menuju Masyarakat Madani dan Lestari, h. 24-33. http://repository.wima.ac.id/9719/1/Prosiding $\% 20$ Seminar $\% 20$ Nasional $\% 20$ Seri $\% 206$ Penelitian 2016.pdf\#page $=40$.

Prasetyaningrum, Purwa. (2016). "Tradisi Rebo Pungkasan di Desa Lebaksiu Lor Kecamatan Lebaksiu Kabupaten Tegal" Sutasoma: Journal of Javanese Literature 4 https://journal.unnes.ac.id/sju/index.php/sutasoma/article/view/29017.

Rachman, Maman. (2012). "Konservasi Nilai dan Warisan Budaya" Indonesian Journal of Conservation 1 30-39. https://journal.unnes.ac.id/nju/index.php/ijc/article/view/2062/2176.

Rahmawati, Rian, et.al. (2017). "Makna Simbolik Tradisi Rebo Kasan" Jurnal Penelitian Komunikasi $20 \quad$ (1): 61-74. http://bppkibandung.id/index.php/jpk/article/download/131/191.

Rohmah, Umi Nuriyatur. (2018). "Penggunaan Ayat-ayat Al-Qur'an dalam Ritual Rebo Wekasan: Studi Living Qur'an di Desa Sukoreno Kec. Kalisat Kab. Jember" Al-Bayan: Jurnal Ilmu al-Qur'an dan Hadis 1 (1): 67-91. http://ejournal.kopertais4.or.id/tapalkuda/index.php/albayan/article/vie $\underline{\mathrm{w} / 3155 / 2342}$ 
Setiawan, Eko. (2017). "Makna Filosofi Wayang Purwa dalam Lakon Dewa Ruci" Kontemplasi: Jurnal Ilmu-ilmu Ushuluddin 5 (2). http://ejournal.iaintulungagung.ac.id/index.php/kon/article/view/870/606.

Setyaningsih, Endang dan Atiek Zahrulianingdyah. (2015). "Adat Budaya Siraman Pengantin Jawa Syarat Makna dan Filosofi" Teknobuga: Jurnal Teknologi Busana dan Boga 2 (2): 1-8. https://journal.unnes.ac.id/nju/index.php/teknobuga/article/view/6427 $\angle 4885$.

Utama, I Gusti Bagus Rai. (2016). "Keunikan Budaya dan Keindahan Alam Sebagai Citra Destinasi Bali Menurut Wisatawan Australia Lanjut Usia" Jurnal Kajian Bali Journal of Bali Studies) 6 (1). https://ojs.unud.ac.id/index.php/kajianbali/article/view/19904.

Wibawa, Sutrisna. (2013). “Nilai Filosofi Jawa dalam Serat Centbini” Litera 12 (2): 328-344.

https://journal.uny.ac.id/index.php/litera/article/view/1546/1276.

Widyastuti, Susana. (__ $)$. "Peribahasa: Cerminan Kepribadian Budaya Lokal dan Penerapannya di Masa Kini." Proceeding of National Seminar of Yogyakarta.

http://staffnew.uny.ac.id/upload/132316016/penelitian/Peribahasa+Cer minan+Kepribadian+Budaya+Lokal.pdf. 